\title{
Effect of substitution of corn for molasses in diet on growth performance, nutrient digestibility, blood characteristics, fecal noxious gas emission, and meat quality in finishing pigs
}

\author{
Shanmugam Sureshkumar ${ }^{1}$, Sang In Lee ${ }^{1}$, Doo Seok Nam², In Ho Kim \\ ${ }^{1}$ Dankook University, Department of Animal Resource \& Science, Cheonan, Choongnam, South Korea. \\ ${ }^{2}$ Konkuk University, Department of Animal Science, Seoul, South Korea.
}

ABSTRACT - The objective of this experiment was to evaluate the effect of molasses as a substitute for corn in diet on growth performance, nutrient digestibility, blood characteristics, fecal noxious gas emission, and meat quality in finishing pigs. A total of 120 [(Landrace $\times$ Yorkshire $) \times$ Duroc] pigs with an average initial body weight $(\mathrm{BW})$ of $54.21 \pm 2.62 \mathrm{~kg}$ were used in this experiment. Pigs were randomly assigned to 1 of the 3 dietary treatments on the basis of BW and sex (10 replicate pens per treatment with four pigs per pen: two gilts and two barrows in each pen). The experiment was divided into two phases: 0-5 weeks and 6-10 weeks. Dietary treatments were as follows: control, basal diet; control $+2.5 \%$ cane molasses; and control $+5 \%$ cane molasses. No significant differences were observed in terms of growth performance, nutrient digestibility, red blood cells, and white blood cells in blood characteristics, fecal noxious gas emission, and meat quality in this study. However, blood lymphocytes were higher with control $+2.5 \%$ cane molasses than with control at the end of the 10th week. Molasses can be considered an alternative for corn at the level of $2.5 \%$ without any negative influence in finishing pigs.

Key Words: body weight, dietary treatments, finishing pig, lymphocyte

\section{Introduction}

Molasses, a mixture of sucrose, glucose, fructose, minerals, pantothenic acid, etc., is derived from sugar-rich crops (beet, cane, blackstrap, etc.) and could be considered an alternative for cereals (Bayley et al., 1983). Cane molasses, which was used in this study, usually contains sucrose, protein, non-protein amino acids, and fatty acids (Mee et al., 1979). It can reduce the cost of diets, because the price of molasses is much lower than that of cereals in livestock feedstuffs. Molasses can also reduce the dust during feed processing and this can improve the environment. However, adding a high level of molasses to the diet of pigs will cause poor growth performance (Brooks and Iwanaga, 1967). These adverse effects may be due to inefficient absorption and utilization of either energy component or fructose in the diet (Bayley et al., 1983). Feoli et al. (2007) reported that adding 5\% molasses to diets containing $40 \%$ distillers dried grains with solubles (DDGS) did not decrease the growth performance in

Received June 10, 2015 and accepted November 27, 2015.

Corresponding author: inhokim@dankook.ac.kr

http://dx.doi.org/10.1590/S1806-92902016000300004

Copyright (c) 2016 Sociedade Brasileira de Zootecnia. This is an Open Access article distributed under the terms of the Creative Commons Attribution License (http://creativecommons.org/licenses/by/4.0/), which permits unrestricted use, distribution, and reproduction in any medium, provided the original work is properly cited. finishing pigs. Molasses or sucrose can be used to replace $50 \%$ or $100 \%$ lactose $(100 \mathrm{~g} / \mathrm{kg})$ in diets for nursery pigs, and it does not have a detrimental influence on the growth performance of pigs (Mavromichalis et al., 2000). There were no detrimental consequences on growth performance in pigs when a proper amount of molasses was added to the diets (Brooks and Iwanaga, 1967). Previous studies assessing the effect of molasses on blood characteristics, fecal noxious gas emission, meat quality, etc. in finishing pigs were inadequate. Therefore, the aim of this experiment was to evaluate the effect of molasses as a substitute for corn on growth performance, nutrient digestibility, blood characteristics, fecal noxious gas emission, and meat quality in finishing pigs.

\section{Material and Methods}

The experimental protocols describing the management and care of animals were reviewed and approved by the Animal Care and Use Committee of Dankook University.

A total of $120[($ Landrace $\times$ Yorkshire $) \times$ Duroc $]$ pigs with an average initial body weight (BW) of $54.21 \pm 2.62 \mathrm{~kg}$ were randomly assigned into three dietary treatments during this 10 -week experiment. The three treatments were as follows: control, basal diet; control $+2.5 \%$ cane molasses; and control $+5.0 \%$ cane molasses. Cane molasses (NongHyup Inc., Seoul, and Republic of Korea) contained water (33\%), 
sucrose $(33 \%)$, other saccharides $(12 \%)$, crude protein $(3 \%)$, minerals $(5 \%)$, sugar-free organic matter $(8 \%)$, and other ingredients $(6 \%)$. Each treatment had 10 replications with four pigs (two gilts and two barrows) per replication. The experiment was divided into two phases: 0-5 weeks and 6-10 weeks. All diets were formulated to meet or exceed the nutrient requirements recommended by NRC (2012) (Table 1). Each pen was provided with a one-sided self-feeder and a nipple drinker that allowed for ad libitum access to feed and water throughout the experiment.

Body weight and feed intake were measured at the beginning of the experiment and at the end of the fifth week and the 10th week of the experiment to calculate average daily gain (ADG), average daily feed intake (ADFI), and gain:feed ratio (G:F). Chromium oxide $\left(\mathrm{Cr}_{2} \mathrm{O}_{3}\right)$ was added to the diet at $0.20 \%$ as an indigestible marker at the beginning of the fifth week and the 10th week to calculate the digestibility coefficient. Fecal grab samples were then collected randomly from at least two pigs in each pen. Feed and fecal samples were dried for $72 \mathrm{~h}$ at $70{ }^{\circ} \mathrm{C}$, after which they were finely ground to be able to pass through a 1-mm screen and then frozen and stored in a refrigerator at $-20{ }^{\circ} \mathrm{C}$ until analysis. Dry matter

Table 1 - Feed compositions of control diet (as-fed basis)

\begin{tabular}{|c|c|c|c|}
\hline & $\mathrm{CON}$ & M2.5 & M5 \\
\hline \multicolumn{4}{|l|}{ Ingredient, \% } \\
\hline Corn & 50.72 & 47.99 & 45.25 \\
\hline Wheat & 15.00 & 15.00 & 15.00 \\
\hline Rice bran & 4.31 & 4.47 & 4.62 \\
\hline Wheat bran & 2.00 & 2.00 & 2.00 \\
\hline Soybean meal & 15.29 & 15.42 & 15.55 \\
\hline DDGS & 7.00 & 7.00 & 7.00 \\
\hline Limestone & 0.78 & 0.73 & 0.68 \\
\hline Animal fat & 3.00 & 3.00 & 3.00 \\
\hline Molasses & 0.00 & 2.50 & 5.00 \\
\hline Salt & 0.30 & 0.30 & 0.30 \\
\hline Choline chloride & 0.02 & 0.01 & 0.01 \\
\hline L-lysine & 0.21 & 0.21 & 0.21 \\
\hline $\mathrm{DCP}$ & 0.99 & 0.99 & 1.00 \\
\hline Mineral premix ${ }^{1}$ & 0.25 & 0.25 & 0.25 \\
\hline Vitamin premix ${ }^{2}$ & 0.13 & 0.13 & 0.13 \\
\hline Total & 100.00 & 100.00 & 100.00 \\
\hline \multicolumn{4}{|c|}{ Calculated composition, $\%$} \\
\hline $\mathrm{ME}, \mathrm{MJ} / \mathrm{kg}$ & 14.51 & 14.41 & 14.31 \\
\hline Crude protein, $\%$ & 15.50 & 15.50 & 15.50 \\
\hline Calcium & 0.65 & 0.65 & 0.65 \\
\hline Phosphorus & 0.60 & 0.60 & 0.60 \\
\hline Lysine & 0.76 & 0.76 & 0.76 \\
\hline
\end{tabular}

$\mathrm{CON}$ - basal diet; M2.5 - CON $+2.5 \%$ molasses; M5 - CON $+5.0 \%$ molasses. DDGS - distillers dried grains with solubles; DCP - dibasic calcium phosphate; ME - metabolizable energy.

${ }^{1}$ Provided per $\mathrm{kg}$ of complete diet: $\mathrm{Cu}$ (as $\mathrm{CuSO}_{4} \cdot 5 \mathrm{H}_{2} \mathrm{O}$ ) - $15 \mathrm{mg}$; $\mathrm{Fe}$ (as FeSO - 7 $\mathrm{H}_{2} \mathrm{O}$ ) - $70 \mathrm{mg}$; $\mathrm{Zn}$ (as $\mathrm{ZnSO}$ ) - $50 \mathrm{mg}$; $\mathrm{Mn}$ (as $\mathrm{MnO}_{2}$ ) - $50 \mathrm{mg}$; I (as $\mathrm{KI}$ ) - $0.5 \mathrm{mg}$; $\mathrm{Co}\left(\right.$ as $\left.\mathrm{CoSO} \cdot 7 \mathrm{H}_{2} \mathrm{O}\right)-0.3 \mathrm{mg}$; $\mathrm{Se}\left(\right.$ as $\left.\mathrm{Na}_{2} \mathrm{SeO} \cdot 5 \mathrm{H}_{2} \mathrm{O}\right)-0.2 \mathrm{mg}$.

${ }^{2}$ Provided per $\mathrm{kg}$ of complete diet: vitamin A - 9,000 IU; vitamin $\mathrm{D}_{3}-1,200 \mathrm{IU}$; vitamin $\mathrm{E}$ - $40 \mathrm{IU}$; vitamin $\mathrm{K}$ (menadione bisulfate complex) - $3.0 \mathrm{mg}$; vitamin $\mathrm{B}_{2}-5.2 \mathrm{mg}$; vitamin $\mathrm{B}_{6}-2.6 \mathrm{mg}$; vitamin $\mathrm{B}_{12}-26 \mu \mathrm{g}$; niacin - $32 \mathrm{mg}$; d-pantothenic acid (as d-calcium pantothenate) - $20 \mathrm{mg}$. and nitrogen $(\mathrm{N})$ concentrations were analyzed according to AOAC (2000). Chromium levels were determined via ultraviolet absorption spectrophotometry (Shimadzu, UV-1201, Japan) and the apparent digestibility of DM and $\mathrm{N}$ was calculated using indirect-ratio methods. The gross energy (GE) was determined by measuring the heat of combustion in the samples using a Parr 6100 oxygen bomb calorimeter (Parr instrument Co., Moline, IL).

At the beginning of the experiment and at the end of the 5th and 10th weeks, two pigs were randomly chosen from each pen and bled via jugular venipuncture to obtain blood samples. At each collection time, the blood samples $(5 \mathrm{~mL})$ were collected into a $\mathrm{K}_{3}$ EDTA vacuum tube (Becton, Dickinson and Co., Franklin Lakes, NJ, USA). All blood samples were centrifuged for $30 \mathrm{~min}$ at $2000 \times \mathrm{g}$ and $4{ }^{\circ} \mathrm{C}$ to separate the serum, after which the white blood cells (WBC), red blood cells (RBC), and lymphocytes were assessed using an automatic biochemistry analyzer (HITACHI 747, Japan).

For analysis of the fecal ammonia and acetic acid concentration, fresh fecal samples were collected from at least two pigs in each pen on the first, third, fifth, and seventh days of the 5th and 10th weeks. The ammonia concentration was then determined using the method described by Chaney and Edward (1962). To determine the fecal acetic acid concentration, $300 \mathrm{~g}$ of fresh fecal samples were transferred to a sealed box and fermented for $30 \mathrm{~h}$ in an incubator $\left(35^{\circ} \mathrm{C}\right)$. The fermented samples were then analyzed using a gas search probe (Gastec Corp., Kanagawa, Japan).

At the end of the experiment, all pigs were slaughtered at a local commercial slaughterhouse. After chilling at $2{ }^{\circ} \mathrm{C}$ for at least $24 \mathrm{~h}$, a piece of the right loin sample was removed between the 10th and 11 th ribs. The meat samples were thawed at an ambient temperature. The lightness $\left(\mathrm{L}^{*}\right)$, redness $\left(a^{*}\right)$, and yellowness $\left(b^{*}\right)$ values were measured at 3 locations on the surface of each sample using a Model CR-410 Chroma meter (Konica Minolta Sensing, Inc., Osaka, Japan). At the same time, duplicate potential of hydrogen $(\mathrm{pH})$ values of each sample was directly measured using a $\mathrm{pH}$ meter (Pittsburgh, PA, USA). The longissimus muscle (LM) area was measured by tracing the LM surface at the 10th rib using a digitizing area-line sensor (MT-10S; M.T. Precision Co. Ltd., Tokyo, Japan). Cook loss was determined as described previously by Sullivan et al. (2007). Drip loss was measured using approximately $2 \mathrm{~g}$ of meat sample according to the plastic bag method described by Honikel (1998).

In the current study, all data were subjected to statistical analysis in a randomized complete block design using the 
GLM procedures of SAS (Statistical Analysis System, version 7.0), with the pen serving as the experimental unit. Variability in the data was expressed as the pooled standard error and a $\mathrm{P}<0.05$ was considered to be statistically significant.

\section{Results}

In both the earlier (0-5 weeks) and the later (6-10 weeks) periods, there was no significant effect of different molasses levels on BW, ADG, ADFI, and G:F ( $P>0.05$; Table 2). Average daily gain, ADFI, and feed conversion parameters were not significantly different during the 5 th wk. None of the contents was significantly affected by different levels of energy during the two periods separately. Average daily gain, ADFI, and feed conversion parameters were not significantly different during the 10 th wk. None of the contents was significantly affected by different levels of energy during the two periods separately.

At the end of the 5th and 10th weeks, there was no significant influence of treatments on the digestibility of $\mathrm{N}$, DM, and GE ( $>0.05$; Table 3). Dry matter, nitrogen, and energy were not significantly affected in finishing pigs during the 5 th to 10 th wk. Dry matter, nitrogen, and energy were not significantly affected by different levels of energy during one period separately; however, by $10 \mathrm{wk}$ of age, the high-energy diet provided higher energy compared with the low-energy diet $(\mathrm{P}<0.05)$.

Table 2 - Effects of molasses supplementation on growth performance in finishing pigs

\begin{tabular}{lcccccc}
\hline & & & & & \multicolumn{2}{c}{ P-value } \\
\cline { 6 - 7 } Item & CON & M2.5 & M5 & SE & Linear & Quadratic \\
\hline BW, kg & & & & & & \\
Initial & 54.8 & 54.2 & 53.6 & 1.6 & 0.1983 & 0.5384 \\
5 weeks & 80.7 & 80.2 & 80.9 & 2.1 & 0.1972 & 0.6731 \\
10 weeks & 111.0 & 111.1 & 111.2 & 2.2 & 0.2365 & 0.7725 \\
5 week & & & & & & \\
ADG, g & 739 & 744 & 781 & 26 & 0.1051 & 0.0739 \\
ADFI, g & 1,971 & 1,905 & 1,925 & 49 & 0.6738 & 0.6738 \\
G:F & 0.375 & 0.391 & 0.406 & 0.014 & 0.6306 & 0.8787 \\
10 week & & & & & & \\
ADG, g & 867 & 884 & 865 & 31 & 0.4472 & 0.3687 \\
ADFI, g & 2,711 & 2,610 & 2,623 & 102 & 0.8310 & 0.5470 \\
G:F & 0.320 & 0.339 & 0.330 & 0.011 & 0.1300 & 0.3206 \\
Overall & & & & & & \\
ADG, g & 803 & 814 & 823 & 13 & 0.2721 & 0.2066 \\
ADFI, g & 2,341 & 2,258 & 2,274 & 57 & 0.2365 & 0.0622 \\
G:F & 0.343 & 0.361 & 0.362 & 0.011 & 0.3542 & 0.195 \\
\hline
\end{tabular}

$\mathrm{CON}$ - basal diet; M2.5 - CON $+2.5 \%$ molasses; $\mathrm{M} 5-\mathrm{CON}+5.0 \%$ molasses; $\mathrm{SE}$ - standard error.

BW - body weight; ADG - average daily gain; ADFI - average daily feed intake; G:F - gain:feed.
The obtained data showed that there were no influences on RBC and WBC when molasses was added to the diets at the beginning, in the fifth week, and at the end of the experiment ( $\mathrm{P}>0.05$; Table 4). Moreover, there was no difference in lymphocytes at the beginning and during the fifth week of the experiment $(\mathrm{P}>0.05)$. However, there was a significant increase in lymphocytes with control $+2.5 \%$ cane molasses compared with control in the 10th week $(\mathrm{P}<0.05)$.

There were no significant effects of dietary treatments on ammonia emission and acetic acid emission at the end of the 5th and 10th weeks ( $>0.05$; Table 5).

Pigs fed diets substituted with molasses showed no difference in meat color, and there was no influence of treatments on the $\mathrm{pH}, \mathrm{LM}$ area, cooking loss, and drip loss ( $\mathrm{P}>0.05$; Table 6).

Table 3 - Effects of molasses supplementation on nutrient digestibility in finishing pigs

\begin{tabular}{lcccccc}
\hline & & & & & \multicolumn{2}{c}{ P-value } \\
\cline { 5 - 7 } Item & CON & M2.5 & M5 & SE & Linear & Quadratic \\
\hline 5 weeks & & & & & & \\
N & 79.17 & 77.80 & 79.99 & 1.62 & 0.1768 & 0.5574 \\
DM & 79.40 & 78.55 & 78.96 & 1.88 & 0.1741 & 0.6148 \\
GE & 76.06 & 78.62 & 76.29 & 1.90 & 0.1523 & 0.7767 \\
10 weeks & & & & & & \\
N & 73.37 & 74.24 & 74.64 & 1.80 & 0.1447 & 0.4928 \\
DM & 74.39 & 73.87 & 76.66 & 1.77 & 0.1512 & 0.5274 \\
GE & 73.28 & 73.70 & 73.53 & 1.98 & 0.1376 & 0.3842 \\
\hline CON - basal diet; M2.5 - CON + 2.5\% molasses; M5 - CON + 5.0\% molasses; \\
SE - standard error. \\
N - nitrogen; DM - dry matter; GE - gross energy.
\end{tabular}

Table 4 - Effects of molasses supplementation on blood characteristics in finishing pigs

\begin{tabular}{|c|c|c|c|c|c|c|}
\hline \multirow{2}{*}{ Item } & \multirow{2}{*}{$\mathrm{CON}$} & \multirow{2}{*}{ M2.5 } & \multirow{2}{*}{ M5 } & \multirow{2}{*}{ SE } & \multicolumn{2}{|c|}{ P-value } \\
\hline & & & & & Linear & Quadratic \\
\hline \multicolumn{7}{|c|}{$\mathrm{RBC}, \times 10^{6} / \mu \mathrm{L}$} \\
\hline Initial & 6.81 & 7.15 & 6.94 & 0.16 & 0.7417 & 0.3384 \\
\hline 5 weeks & 7.32 & 7.48 & 7.63 & 0.34 & 0.0556 & 0.9310 \\
\hline 10 weeks & 7.83 & 10.74 & 11.41 & 2.25 & 0.1006 & 0.3858 \\
\hline \multicolumn{7}{|c|}{$\mathrm{WBC}, \times 10^{3} / \mu \mathrm{L}$} \\
\hline Initial & 17.43 & 18.37 & 18.14 & 1.38 & 0.0196 & 0.6153 \\
\hline 5 weeks & 25.97 & 25.96 & 26.22 & 0.47 & 0.8660 & 0.5674 \\
\hline 10 weeks & 24.17 & 27.50 & 28.54 & 2.04 & 0.0845 & 0.3005 \\
\hline \multicolumn{7}{|c|}{ Lymphocyte, \% } \\
\hline Initial & 53.10 & 52.78 & 52.54 & 2.32 & 0.1658 & 0.0083 \\
\hline 5 weeks & 58.95 & 63.02 & 65.30 & 3.96 & 0.2305 & 0.7767 \\
\hline 10 weeks & $63.15 b$ & $69.78 \mathrm{a}$ & $67.78 \mathrm{ab}$ & 2.03 & 0.1658 & 0.0083 \\
\hline
\end{tabular}

CON - basal diet; M2.5 - CON $+2.5 \%$ molasses; M5 - CON $+5.0 \%$ molasses; $\mathrm{SE}$ - standard error.

$\mathrm{RBC}$ - red blood cells; WBC - white blood cells.

$\mathrm{a}, \mathrm{b}-$ means in the same row with different letters differ $(\mathrm{P}<0.05)$. 
Table 5 - Effects of molasses supplementation on fecal noxious gas emission in finishing pigs

\begin{tabular}{|c|c|c|c|c|c|c|}
\hline \multirow{2}{*}{ Item } & \multirow{2}{*}{$\mathrm{CON}$} & \multirow{2}{*}{ M2.5 } & \multirow{2}{*}{ M5 } & \multirow{2}{*}{$\mathrm{SE}$} & \multicolumn{2}{|c|}{ P-value } \\
\hline & & & & & Linear & Quadratic \\
\hline \multicolumn{7}{|c|}{5 weeks } \\
\hline \multicolumn{7}{|c|}{ Ammonia } \\
\hline 1 day & 14.8 & 13.1 & 12.6 & 1.7 & 0.2098 & 0.9820 \\
\hline 3 days & 18.9 & 19.2 & 19.1 & 1.0 & 0.5230 & 0.7007 \\
\hline 5 days & 19.4 & 21.4 & 21.4 & 0.9 & 0.3195 & 0.1855 \\
\hline 7 days & 24.6 & 24.5 & 21.3 & 2.3 & 0.5973 & 0.5827 \\
\hline \multicolumn{7}{|c|}{ Acetic acid } \\
\hline 1 day & 15.0 & 13.0 & 13.9 & 0.8 & 0.7869 & 0.4760 \\
\hline 3 days & 19.5 & 16.0 & 16.7 & 1.4 & 0.9069 & 0.3838 \\
\hline 5 days & 35.5 & 37.1 & 37.3 & 3.1 & 0.3882 & 0.1841 \\
\hline 7 days & 26.7 & 22.6 & 25.8 & 1.4 & 0.6138 & 0.5472 \\
\hline \multicolumn{7}{|c|}{10 weeks } \\
\hline \multicolumn{7}{|c|}{ Ammonia } \\
\hline 1 day & 13.3 & 12.5 & 11.1 & 2.1 & 0.3782 & 0.4275 \\
\hline 3 days & 16.5 & 15.9 & 15.6 & 0.6 & 0.9839 & 0.8844 \\
\hline 5 days & 19.0 & 19.5 & 18.7 & 0.7 & 0.1464 & 0.2796 \\
\hline 7 days & 18.4 & 17.6 & 16.8 & 1.9 & 0.5819 & 0.3453 \\
\hline \multicolumn{7}{|c|}{ Acetic acid } \\
\hline 1 day & 15.2 & 14.6 & 15.6 & 1.2 & 0.5774 & 0.6306 \\
\hline 3 days & 17.9 & 17.5 & 17.7 & 0.5 & 0.5916 & 0.5597 \\
\hline 5 days & 27.1 & 26.8 & 25.5 & 0.8 & 0.3464 & 0.5855 \\
\hline 7 days & 21.6 & 20.6 & 20.3 & 0.5 & 0.5841 & 0.5627 \\
\hline
\end{tabular}

CON - basal diet; $\mathrm{M} 2.5-\mathrm{CON}+2.5 \%$ molasses; $\mathrm{M} 5-\mathrm{CON}+5.0 \%$ molasses; SE - standard error.

Table 6 - Effects of molasses supplementation on meat quality in finishing pigs

\begin{tabular}{|c|c|c|c|c|c|c|}
\hline \multirow{2}{*}{ Item } & \multirow{2}{*}{$\mathrm{CON}$} & \multirow{2}{*}{ M2.5 } & \multirow{2}{*}{ M5 } & \multirow{2}{*}{$\mathrm{SE}$} & \multicolumn{2}{|c|}{ P-value } \\
\hline & & & & & Linear & Quadratic \\
\hline \multicolumn{7}{|l|}{ Meat color } \\
\hline $\mathrm{L}^{*}$ & 57.76 & 55.36 & 55.77 & 1.70 & 0.1528 & 0.2265 \\
\hline$a^{*}$ & 16.80 & 15.87 & 18.25 & 1.12 & 0.9189 & 0.7149 \\
\hline$b^{*}$ & 9.68 & 8.02 & 8.94 & 0.58 & 0.2695 & 0.3862 \\
\hline $\mathrm{pH}$ & 5.84 & 5.65 & 5.63 & 0.05 & 0.2186 & 0.5491 \\
\hline $\mathrm{LM}$ area, $\mathrm{cm}^{2}$ & 48.27 & 48.58 & 50.31 & 1.90 & 0.3655 & 0.4582 \\
\hline Cooking loss, $\%$ & 23.88 & 21.37 & 20.32 & 3.12 & 0.4892 & 0.6892 \\
\hline Drip loss, $\%$ & & & & & & 0.4357 \\
\hline 1 day & 5.11 & 3.45 & 3.85 & 1.47 & 0.3281 & 0.2956 \\
\hline 3 day & 5.86 & 5.94 & 5.79 & 1.42 & 0.5823 & 0.5643 \\
\hline 5 day & 6.61 & 8.91 & 8.44 & 1.59 & 0.1984 & 0.2846 \\
\hline 7 day & 9.02 & 12.01 & 9.77 & 1.71 & 0.2561 & 0.3184 \\
\hline
\end{tabular}

CON - basal diet; M2.5 - CON $+2.5 \%$ molasses; $\mathrm{M} 5-\mathrm{CON}+5.0 \%$ molasses; SE - standard error.

$\mathrm{pH}$ - potential of hydrogen; LM - longissimus muscle.

\section{Discussion}

It has been reported that $5 \%$ molasses in the diet may have no effect on ADG in finishing pigs (George et al., 1949; Feoli et al., 2007), which was in agreement with results of the present study. The reason for this may be the nutrient digestibility, because there was no significant influence in nutrient digestibility in this study. There was no influence of treatments with 0,5 , and $10 \%$ invert cane molasses on BW,
ADG, and G:F, respectively, in early weaned pigs (Diaz et al., 1956). Similar results were obtained, which showed that adding 20\% molasses to the diet does not affect ADG (Brooks, 1967) and G:F (Brooks, 1972) in growing pigs compared with the treatments containing a lower level of molasses. There was no significant effect on BW and ADG in growing pigs fed 200, 400,600, and $800 \mathrm{~g} / \mathrm{d}$ of molasses, respectively (Xandé et al., 2010). However, there were some differences in the results. Addition of $49.8 \%$ molasses to growing swine diets can reduce the ADG and G:F compared with that in the corn basal group and 10\% molasses group (Brooks and Iwanaga, 1967). It was observed that G:F was significantly decreased in pigs fed the diet containing 5\% molasses. O'Grady et al. (1971) reported that the addition of 5\% molasses significantly improved the daily gain and feed intake and increased the feed efficiency when BW was less than $25 \mathrm{~kg}$, and after that, smaller effects or no effects on daily gain and feed intake were observed in pigs fed the diet containing 5\% molasses. However, comparisons are complicated because of different stages of pigs, the level of added molasses, housing environment, etc.

Inclusion of molasses did not affect the N, DM, and GE digestibility in this study. Similar results were obtained, which showed that the apparent digestibility of DM and $\mathrm{N}$ was not influenced by the different levels of final molasses $(23.5 \%, 39.5 \%$, and $55.5 \%)$ in growing pigs (Velázquez et al., 1969). One of the trials in growing swine performed by Brooks (1967) demonstrated that DM digestibility was not influenced by $20 \%$ molasses treatment compared with the basal group (without molasses). However, digestibility was decreased with the highest level of condensed molasses solubles (of DM by 43\%) in finishing pigs (Stemme et al., 2005). Compared with starch treatment, digestibilities of $\mathrm{DM}$ and energy were significantly reduced in the treatment containing $68.5 \%$ molasses in growing pigs (Bayley et al., 1983). Brooks (1967) reported that DM digestibility was much lower in growing pigs fed the diet containing $20 \%$ molasses compared with the basal group (without molasses). On the contrary, Brooks and Iwanaga (1967) reported that the high-level molasses treatment $(49.8 \%)$ had a greater digestible energy than both the lowermolasses-level treatment (10\%) and basal group (without molasses). According to the previous reports and this research, although not all studies showed similar results, a high level of molasses might reduce the N, DM, and energy digestibility in pigs and there was no adverse effect with a low level of molasses (less than $5 \%$ ).

In this study, although there were no significant differences in $\mathrm{RBC}$ and WBC among groups, blood lymphocytes were significantly increased with control 
$+2.5 \%$ cane molasses compared with control in the 10th week. Lymphocytes are one of the main cells of the immune system. Low concentration of ammonia may lead to high immunity in livestock (Yan et al., 2011). There was no significant difference in fecal ammonia concentration, but ammonia concentration was lower in pigs fed control + $2.5 \%$ cane molasses compared with pigs fed control in the 10th week. This could be one of the reasons for the present result. Another reason may be the unidentified material in the molasses, whose function has not been proved. There is no report on this material; therefore, more evidence is required to prove this result.

Fecal noxious gas emission can indirectly indicate the health of the pigs and can directly affect the housing environment. Poor housing environment may cause health problems in pigs. In this study, there was no significant difference in fecal noxious gas emission among the treatments. There are no reports on the effect of molasses on fecal noxious gas emission, and there are only some studies assessing the effect of molasses on the DM in feces (Velázquez et al., 1969; Perez et al., 1983; Stemme et al., 2005). Therefore, it is difficult to explain the results of this study, and more studies on this aspect are needed. Higher amount of fecal noxious gas emission and worse housing environment were not observed; thus, according to this study, there was no adverse influence on housing environment in finishing pigs whose diet contained molasses.

There were no significant differences in meat quality among treatments. Studies also reported similar results, which suggests that molasses did not affect the meat quality of pigs compared with control diet (Karamitros, 1987; Xandé et al., 2010). The diet containing $20 \%$ molasses did not increase the loin eye area in weaning pigs (Brooks, 1967). However, Brooks and Iwanaga (1967) reported that the pigs fed the diet containing $37.4 \%$ molasses and $12.3 \%$ fat had a higher loin eye area and a lower dressing percentage compared with the pigs fed corn basal diets. These differences may be due to the amount of molasses, growth stage, etc.

According to the results, fecal noxious gas emission did not increase with control $+5.0 \%$ cane molasses; therefore, there was no harm to the housing environment in this study. Moreover, adding a low level of molasses (2.5\%) to the diet can increase blood lymphocytes in pigs.

\section{Conclusions}

Molasses can be considered a replacement for corn in finishing pig diets at the level of $2.5 \%$ without any negative effects. It can improve growth performance, while improving meat marbling and firmness score.

\section{Acknowledgments}

We gratefully acknowledge the analysis supported by the laboratory members at Dankook University, Department of Animal Resource \& Science, Cheonan, Choongnam, South Korea.

\section{References}

AOAC - Association of Official Analytical Chemistry. 2000. Official methods of analysis. 17th ed. AOAC, Arlington, VA.

Brooks, C. C. 1967. Effect of sex, fat, fibre, molasses and thyroprotein on digestibility of nutrients and performance of growing swine. Journal of Animal Science 26:495-499.

Brooks, C. C. and Iwanaga, I. I. 1967. Use of cane molasses in swine diets. Journal of Animal Science 26:741-745.

Brooks, C. C. 1972. Molasses, sugar (sucrose), corn, tallow, soybean oil and mixed fats as sources of energy for growing swine. Journal of Animal Science 34:217-224.

Bayley, H. S.; Figueroa, V.; Ly, J.; Maylin, A. and Perez, A. 1983. Utilization of sugarcane final molasses by the pig: energy metabolism. Czech Journal of Animal Science 63:455-462.

Chaney, A. L. and Edward, P. M. 1962. Modified reagents for determination of urea and ammonia. Clinical Chemistry 8:130-132.

Diaz, F.; Speer, V. C.; Ashton, G. C.; Liu, C. H. and Catron, D. V. 1956. Comparison of refined cane sugar, invert cane molasses and unrefined cane sugar in starter rations for early weaned pigs. Journal of Animal Science 15:315-319.

Feoli, C.; Hancock, J. D.; Williams, S. M.; Gugle, T. L.; Carter, S. D. and Cole, N. A. 2007. Effects of dietary electrolyte balance and molasses in diets with corn-based distillers dried grains with solubles on growth performance in nursery and finishing pigs. Journal of Animal Science 85(Suppl 1):648.

George, W.; Noot, V. and Skelley, W. C. 1949. Dried molasses, potato, or corn distillers' solubles as part of a ration for fattening pigs in drylot. Journal of Animal Science 8:123-131.

Honikel, K. O. 1998. Reference methods of the assessment of physical characteristics of meat. Meat Science 49:447-457.

Karamitros, D. 1987. Sugar beet molasses for growing and fattening pigs. Animal Feed Science and Technology 18:131-142.

Mavromichalis, I.; Hancock, J. D.; Hines, R. H.; Senne, B. W. and Cao, H. 2000. Lactose, sucrose, and molasses in simple and complex diets for nursery pigs. Animal Feed Science and Technology 93:127-135.

Mee, J. M. L.; Brooks, C. C. and Stanley, R. W. 1979. Amino acid and fatty acid composition of cane molasses. Journal of the Science of Food and Agriculture 30:429-432.

NRC - National Research Council. 2012. Nutrient requirements of swine. 11th rev. ed. National Academic Press, Washington, D.C., USA.

O'Grady, J. F. and Bowland, J. P. 1971. Response of early weaned pigs to diets of different digestible energy concentrations and the effects of cereal source and added molasses on performance. Czech Journal of Animal Science 52:87-96.

Perez, A.; Figueroa, V.; Ly, J.; Maylin, A. and Bayley, H. S. 1983. Utilization of sugar cane final molasses by the pig: composition of ileal digesta. Czech Journal of Animal Science 64:147-158.

Stemme, K.; Gerdes, B.; Harms, A. and Kamphues. J. 2005. Beetvinasse (condensed molasses solubles) as an ingredient in diets for cattle and pigs - nutritive value and limitations. Journal of Animal Physiology and Animal Nutrition 89:179-183. 
Sullivan, Z. M.; Honeyman, M. S.; Gibson, L. R. and Prusa, K. J. 2007. Effects of triticale-based diets on finishing pig performance and pork quality in deep-bedded hoop barns. Meat Science 76:428-437.

Velázquez, M.; Ly, J. and Perston, T. R. 1969. Digestible and metabolizable energy values for pigs of diets based on high-test molasses or final molasses and sugar. Journal of Animal Science 29:578-580.
Xandé, X.; Archimède, H.; Gourdine, J. L.; Anais, C. and Renaudeau, D. 2010. Effects of the level of sugarcane molasses on growth and carcass performance of Caribbean growing pigs reared under a ground sugarcane stalks feeding system. Tropical Animal Health and Production 42:13-20.

Yan, L.; Meng, Q. W. and Kim, I. H. 2011. The effect of an herb extract mixture on growth performance, nutrient digestibility, blood characteristics and fecal noxious gas content in growing pigs. Livestock Science 141:143-147. 